\title{
SOME SURFACE PROPERTIES OF THERMALLY MODIFIED SCOTS PINE AFTER ARTIFICIAL WEATHERING
}

\author{
Ergun Baysal ${ }^{1, \star}$, Selim Degirmentepe ${ }^{1}$, Hakan Simsek ${ }^{2}$
}

\begin{abstract}
In this study, it was aimed to investigate some surface characteristics such as surface roughness, color, and glossiness of Scots pine (Pinus sylvestris) wood specimens after 500 hours artificial weathering exposure. The results showed that surface characteristics of thermally modified Scots pine gave better results than unmodified Scots pine after artificial weathering. Artificial weathering caused an increase in surface roughness and a decrease in glossiness of Scots pine wood. Results showed artificial weathered wood become darker, reddish, and yellowish. Generally, higher duration and temperature for Scots pine resulted in better surface characteristics of Scots pine after artificial weathering.
\end{abstract}

Keywords: Scots pine, thermal modification, artificial weathering, surface roughness, glossiness, color

\section{INTRODUCTION}

Thermal treatment or heat treatment is a way of drastically changing the properties of wood and in some sense of producing a "new material". During the last decade, heat-treated wood has been commercialized and produced on a large scale (Sundqvist 2004). Heat treatment of wood changes its chemical composition by degrading both cell wall compounds and extractive (Esteves et al. 2008). The thermal modification of wood has been known as a process enhancing wood properties by reducing moisture absorption, improving dimensional stability and biological durability (Akgul and Korkut 2012). However, the loss of strength has always been one of the main drawbacks for the commercial utilization of thermally treated wood. (Gunduz and Aydemir 2009). With heat treatment, the colour of wood is modified acquiring a darker tonality which is often justified by the formation of colour degradation produced from hemicelluloses (Sehlstedt-Persson 2003, Sundqvist 2004). Color of wood is important from the viewpoint of aesthetic and hedonic concepts for the consumers. Depending on culture, country, and income level, wood products may have higher market volume solely due to its color. Heat treatment provides an inexpensive alternative method to darken wood to imitate more expensive exotic species (Korkut et al. 2013).

Wood surfaces exposed outdoors are rapidly degraded because lignin strongly absorbs UV light, which leads to radical-induced depolymerisation of lignin and cellulose, the major structural constituents of wood (Evans et al. 2002). The yellowing, browning and/or graying of wood surfaces exposed outdoors indicate the modification of lignin. The depolymerisation of lignin and cellulose lead also to the reduction of some physical, chemical, and biological properties of wood (Grelier et al. 2000). Changes in chemical and optical properties belong to physical properties of wood lead to discoloration, loss of gloss, roughening of surface, and are also accompanied by alteration of mechanical properties of the three main components of wood-cellulose, hemicelluloses, and lignin appears to be oxidized and

\footnotetext{
${ }^{1}$ Mugla Sitki Kocman University, Faculty of Technology, Department of Wood Science and Technology, Kotekli 48000, Mugla, Turkey

${ }^{2}$ Gaziosmanpasa University, Vocational High School of Technical Sciences, Department of Wood Science and Technology, Merkez, 60100, Tokat, Turkey

^Corresponding author: bergun@mu.edu.tr

Received: 28.06. 2013 Accepted: 11.11.2013.
} 
degraded by UV light more rapidly (Denes and Young 1999). Out of all environmental factors, what contributes most to the weathering of wood is light (Feist and Hon 1984). To limit wood photodegradation, many chemical protections were investigated: chemical modification of wood (Beckers et al. 1998, Rowell 1983, Hill 2006, Evans et al. 2002, Pandey and Chandrashekar 2006, Jebrane and Se 'be 2007, Jebrane and Sébe 2008), the grafting of UV absorbers (Williams 1983, Grelier et al. 1997, Kiguchi and Evans 1998), treatment with inorganic salts, particularly hexavalent chromium compounds (Baysal 2012, Evans et al. 1992, Yalinkilic et al. 1999, Feist 1979). More than $95 \%$ of exterior wood coatings are applied as liquid coatings with either organic solvent or water as the carrier for the other coatings ingredients. The use and subsequent emission of volatile organic compounds (VOCs) to the environment has been increasingly considered as a problem during the last 20 years from the both an air-pollution and health and safety point of view (Meijer 2001). Also, health concerns about the use of hexavalent chromium have also discouraged commercial development of this concept (Kiguchi and Evans 1998). When compared to untreated wood, heat-treated wood shows greater resistance to weathering (Temiz et al. 2006, Nuopponen et al. 2004, Ayadi et al. 2003). The modified chromophoric lignin structure due to heat treatment may interfere with light absorption process, thereby inducing photo-stability (Srinivas and Pandey 2012). Investigations on surface characteristics of heat-treated wood after exposure to artificial weathering are very limited and the effects of weathering on heated wood species are not well known. It is possible to maximize the service life of heat treated wood products in any type of climatic conditions by understanding and predicting the protection mechanism against weathering factors (Yildiz et al. 2013). In this study, it was aimed to investigate some surface characteristics such as surface roughness, gloss, and color of thermally modified Scots pine wood after artificial weathering exposure.

\section{MATERIAL AND METHODS}

\section{Preparation of test specimens}

Specimens $6 \times 75 \times 150 \mathrm{~mm}$ (radial by tangential by longitudinal) were machined from the air-dried sapwood of Scots pine (Pinus sylvestris L.) lumber. All specimens were conditioned at $20^{\circ} \mathrm{C}$ and $65 \%$ relative humidity for two weeks before tests.

\section{Thermal modification}

Thermal modification was performed using a temperature-controlled laboratory oven. Three different temperatures $\left(140^{\circ} \mathrm{C}, 170^{\circ} \mathrm{C}\right.$, and $\left.200^{\circ} \mathrm{C}\right)$ and three treatment durations $(2,4$, and $8 \mathrm{~h})$ were applied to wood specimens under atmospheric pressure and in the presence of air.

\section{Artificial weathering}

Artificial weathering experiment was performed in a QUV weathering device (Q - Lab, USA) equipped with eight UVA 340 lamps according to principles of ASTM G154 (2006) standard. Specimens were exposed to cycles of $8 \mathrm{~h}$ UV-light irradiation followed by condensation for $4 \mathrm{~h}$ in QUV device for a total of $500 \mathrm{~h}$. The average irradiance was $0.89 \mathrm{~W} / \mathrm{m}^{2}$ at the maximum intensity of $340 \mathrm{~nm}$ wavelengths $(\lambda \max =340 \mathrm{~nm})$. The temperature at the light irradiation period and at the condensation period was $60^{\circ} \mathrm{C}$ and $50^{\circ} \mathrm{C}$, respectively. Since the moisture content is an important parameter affecting the properties of wood, specimens were conditioned at $20^{\circ} \mathrm{C}$ and $65 \%$ relative humidity until constant weight was achieved before and after artificial weathering experiment. Therefore, surface roughness, glossiness, and color measurements were performed on conditioned specimens and the measurements were not affected by having different moisture content of specimens before and after weathering. 


\section{Surface roughness}

The Mitutoyo Surftest SJ-301 instrument was employed for surface roughness measurements according to DIN 4768 (1990). Three roughness parameters which are mean arithmetic deviation of profile $(R a)$, mean peak-to-valley height $(R z)$, and root mean square $(R q)$ and these parameters were widely employed in former studies to evaluate surface characteristics of wood and wood based materials (Hiziroglu 1996, Hiziroglu and Graham 1998).

\section{Color test}

The color parameters $a^{*}, b^{*}$, and $L^{*}$ were determined by the CIELAB method. The $L^{*}$ axis represents the lightness, whereas $a^{*}$ and $b^{*}$ are the chromaticity coordinates. The $+a^{*}$ and $-a^{*}$ parameters represent red and green, respectively. The $+b^{*}$ parameter represents yellow, whereas $-b^{*}$ represents blue. $L^{*}$ can vary from 100 (white) to zero (black) (Zhang 2003). The colors of the specimens were measured by a color meter (X-Rite SP Series Spectrophotometer) before and after artificial weathering. The measuring spot was adjusted to be equal or not more than one-third of the distance from the center of this area to the receptor field stops. The color difference, $\left(\Delta E^{*}\right)$ was determined for each wood as follows (ASTM D 1536-58 1964):

$$
\begin{aligned}
& \Delta a^{*}=a_{f}^{*}-a^{*} \\
& \Delta b^{*}=b^{*}-b^{*}{ }_{i} \\
& \Delta L^{*}=L_{f}{ }^{*} L^{*} \\
& \left(\Delta E^{*}\right)=\left[\left(\Delta a^{*}\right)^{2}+\left(\Delta b^{*}\right)^{2}+\left(\Delta L^{*}\right)^{2}\right]^{1 / 2}
\end{aligned}
$$

where: $\Delta a^{*}, \Delta b^{*}$, and $\Delta L^{*}$ are the changes between the initial and final interval values.

\section{Glossiness test}

The glossiness of wood specimens was determined using a gloss meter (BYK Gardner, MicroTRI-Gloss) according to ASTM D523-08 (2008). The chosen geometry was an incidence angle of $60^{\circ}$. Results were based on a specular gloss value of 100 , which relates to the perfect condition under identical illuminating and viewing conditions of a highly polished, plane, black glass surface.

\section{Evaluations of test results}

Surface roughness, glossiness, and color tests results were evaluated by a computerized statistical program composed of analysis of variance and following Duncan tests at the $95 \%$ confidence level. Statistical evaluations were made on homogeneity groups (HG), of which different letters reflected statistical significance.

\section{Surface roughness}

\section{RESULTS AND DISCUSSIONS}

Surface roughness parameters such as $R a, R z$, and $R q$ values of artificially weathered Scots pine wood are given in table 1. Also, they are given in figure 1, figure 2, and figure 3, respectively. Unmodified Scots pine (control) specimen had an average $R a, R z$, and $R q$ values 3,22; 19,38; and 4,12 respectively after artificial weathering. Our result showed that surface roughness of unmodified Scots pine wood was higher than thermally modified Scots pine wood after artificial weathering. This increase in surface roughness is very important for many applications of solid wood. The wooden materials with rough surface requires much more sanding process compared to one with smooth surface, which leads to decrease in thickness of material and, therefore, increases the losses due to the sanding process (Dundar et al. 2008). However, wood is heterogeneous, anisotropic and brittle material. The surface roughness of wood products depends on many factors such as wood anatomical structural (vessels, cell lumen, annual ring width, hardness etc.), machine conditions (feed rate, spindle speed etc.) and cutting 
properties (Karagoz et al. 2011). Artificial weathering increased surface roughness of both unmodified and thermally modified Scots pine. While the increase of $R a, R z$, and $R q$ were $56,31 \% ; 42,81 \%$ and $52,02 \%$ respectively for unmodified Scots pine, the increase of $R a$ was from $12,19 \%$ to $36,69 \% R z$ was from $10,36 \%$ to $18,57 \%$ and $R q$ was from $11,98 \%$ to $27,20 \%$, for thermally modified Scots pine. There were statistical differences between $R a, R z$, and $R q$ values of unmodified Scots pine wood and thermally modified Scots pine after artificial weathering. Yildiz et al. (2013) reported that heat treatment seemed to protect wood surface from becoming rougher after weathering for softwood. Our results are in good agreement with this researcher's finding. According to our results, higher temperature and duration resulted in lower surface roughness of Scots pine wood after artificial weathering.

Table 1. Surface roughness of Scots pine (Pinus sylvestris) before and after artificial Weathering.

\begin{tabular}{|c|c|c|c|c|c|c|c|c|c|c|c|c|c|}
\hline \multirow[t]{2}{*}{ Temp. } & \multirow[t]{2}{*}{ Hours } & \multicolumn{3}{|c|}{ Before artificial weathering } & \multicolumn{3}{|c|}{ After artificial weathering } & \multicolumn{3}{|c|}{ Differences } & \multicolumn{3}{|c|}{ Differences $(\%)$} \\
\hline & & $\mathrm{Ra}$ & $\mathrm{Rz}$ & $\mathrm{Rq}$ & $\mathrm{Ra}$ & $\mathrm{Rz}$ & $\mathrm{Rq}$ & $\mathrm{Ra}$ & $\mathrm{Rz}$ & $\mathrm{Rq}$ & $\mathrm{Ra}$ & $\mathrm{Rz}$ & $\mathrm{Rq}$ \\
\hline Unmodified & & $2,06(0,82)$ & $13,57(5,14)$ & $2,71(1,08)$ & $3,22(0,88)$ & $19,38(4,19)$ & $4,12(1,37)$ & $1,16^{\mathrm{f}}$ & $5,81^{\mathrm{d}}$ & $1,41^{\mathrm{e}}$ & 56,31 & 42,81 & 52,02 \\
\hline \multirow[t]{2}{*}{140} & 4 & $2,65(0,59)$ & $17,55(3,20)$ & $3,56(0,85)$ & $3,45(0,56)$ & $20,64(6,50)$ & $4,46(1,04)$ & $0,80^{\text {de }}$ & $3,09^{\mathrm{c}}$ & $0,90^{\mathrm{d}}$ & 30,19 & 17,60 & 25,28 \\
\hline & 8 & $2,46(0,88)$ & $14,90(4,54)$ & $3,16(1,23)$ & $3,07(1,32)$ & $17,44(5,94)$ & $3,84(1,35)$ & $0,61^{\text {cd }}$ & $2,54^{\mathrm{bc}}$ & $0,68^{\mathrm{cd}}$ & 24,79 & 17,04 & 21,51 \\
\hline \multirow[t]{3}{*}{170} & 4 & $2,32(0,47)$ & $14,94(4,06)$ & $2,99(0,60)$ & $2,73(0,57)$ & $16,60(3,99)$ & $3,54(1,52)$ & $0,41^{\mathrm{abc}}$ & $1,66^{\mathrm{a}}$ & $0,55^{\text {abc }}$ & 17,67 & 11,11 & 18,39 \\
\hline & 8 & $2,25(0,26)$ & $13,84(2,30)$ & $2,86(0,35)$ & $2,56(0,81)$ & $15,29(4,68)$ & $3,34(1,57)$ & $0,31^{\mathrm{ab}}$ & $1,45^{\mathrm{a}}$ & $0,48^{\mathrm{abc}}$ & 13,77 & 10,47 & 16,78 \\
\hline & 2 & $2,40(0,77)$ & $19,10(4,50)$ & $4,55(1,13)$ & $2,89(0,83)$ & $21,93(4,92)$ & $5,26(1,98)$ & $0,49^{\mathrm{bc}}$ & $2,83^{\text {abc }}$ & $0,71^{\text {abc }}$ & 20,41 & 14,81 & 15,60 \\
\hline \multirow[t]{2}{*}{200} & 4 & $2,15(0,45)$ & $14,54(2,43)$ & $2,87(0,56)$ & $2,54(1,13)$ & $16,27(4,08)$ & $3,25(1,43)$ & $0,39^{\mathrm{abc}}$ & $1,73^{\mathrm{ab}}$ & $0,38^{\mathrm{ab}}$ & 18,30 & 11,89 & 13,24 \\
\hline & 8 & $2,05(0,62)$ & $13,41(3,53)$ & $2,17(0,83)$ & $2,30(0,68)$ & $14,80(4,34)$ & $2,43(0,85)$ & $0,25^{\mathrm{a}}$ & $1,39^{\mathrm{a}}$ & $0,26^{\mathrm{a}}$ & 12,19 & 10,36 & 11,98 \\
\hline
\end{tabular}

Note: Five replications were made for each group. Small letters given as superscript over $R a, R z$, and $R q$ values represent homogeneity groups (HG) obtained by statistical analysis with similar letters reflecting statistical insignificance at the $95 \%$ confidence level. Values in parenthesis are standard deviations.

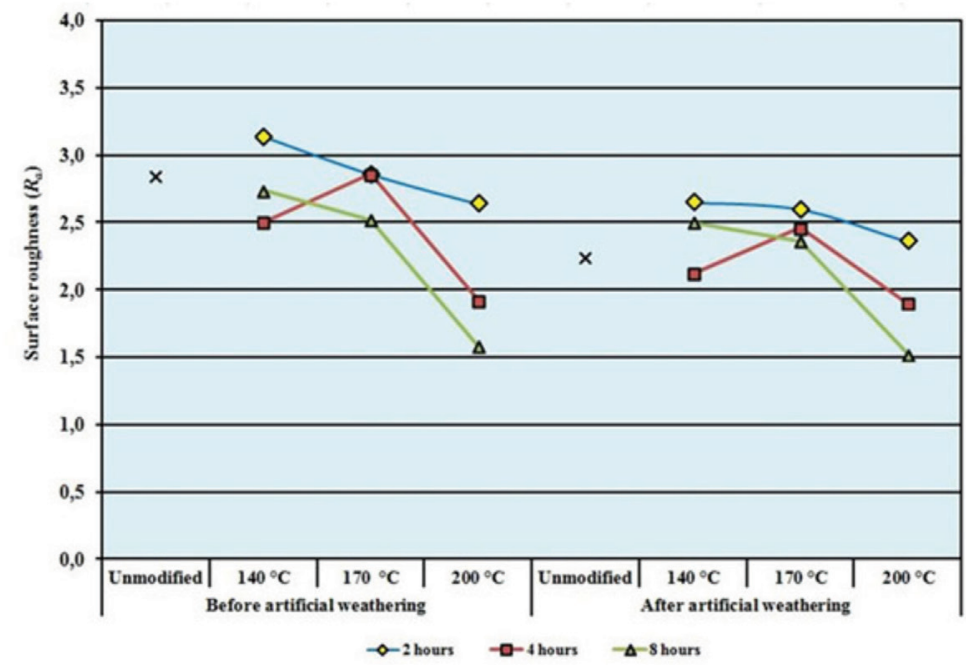

Figure 1. $R a$ values of unmodified and thermally modified Scots pine (Pinus sylvestris) after artificial weathering. 


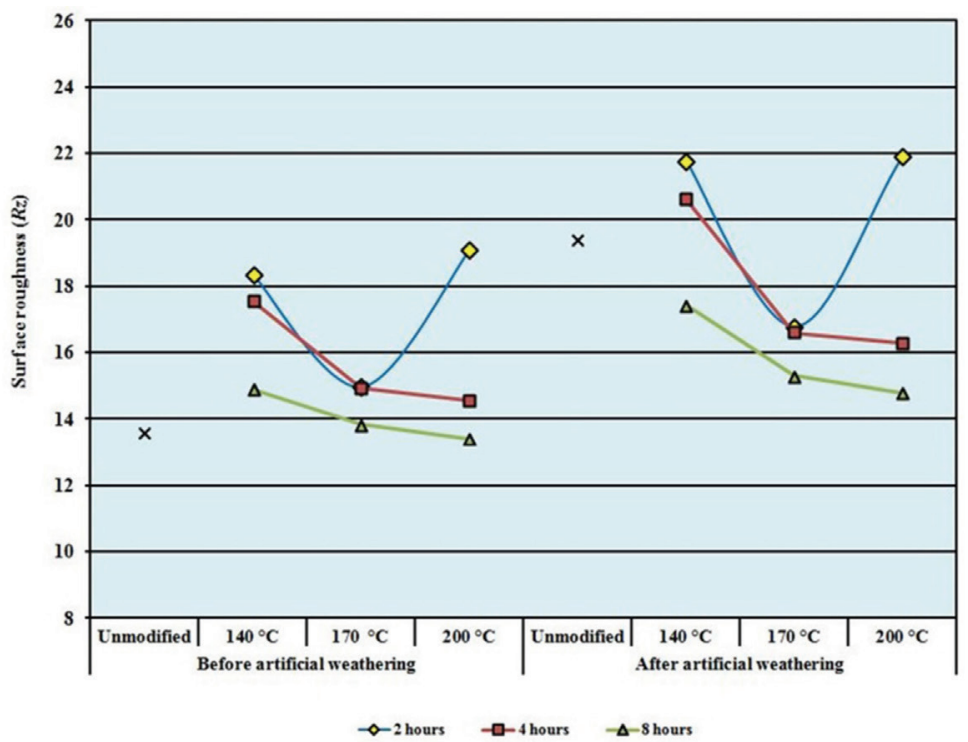

Figure 2. Rz values of unmodified and thermally modified Scots pine (Pinus sylvestris) after artificial weathering.

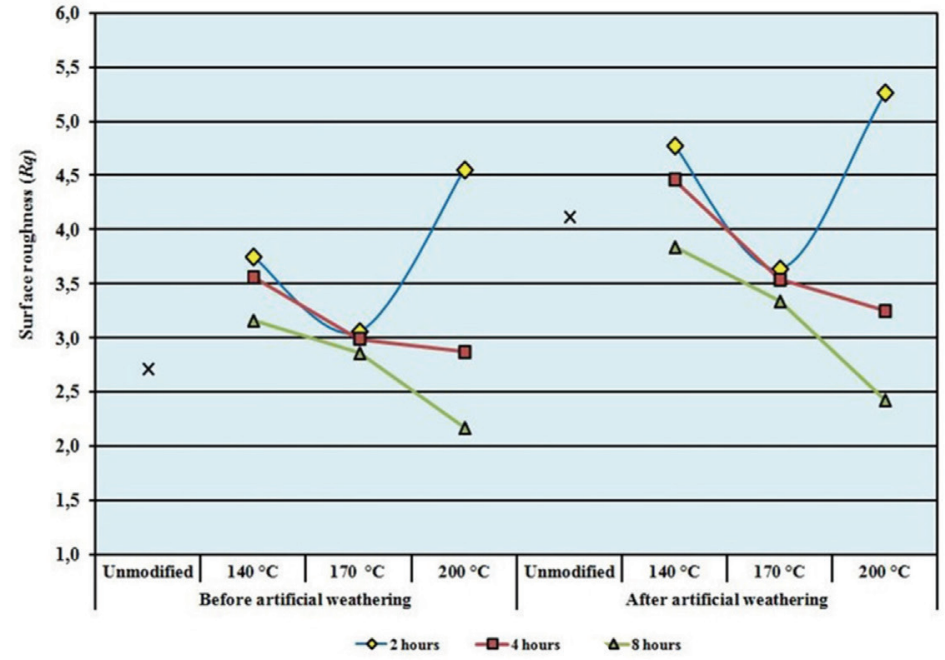

Figure 3. $R q$ values of unmodified and thermally modified Scots pine (Pinus sylvestris) after artificial weathering. 


\section{Glossiness}

Glossiness values of the wood surfaces at a $60^{\circ}$ incidence angle measured for Scots pine wood before and after artificial weathering are given in Table 2 and Figure 4. Glossiness, a property of reflecting light in a mirror-like fashion, is very important for an aesthetic and decorative appearance of coated wood surface (Cakicier et al. 2011). While the lowest glossiness value was 1,51 recorded of thermally modified Scots pine for $4 \mathrm{~h}$ at $200^{\circ} \mathrm{C}$, the highest glossiness was 2,65 measured for thermally modified Scots pine for $2 \mathrm{~h}$ at $140{ }^{\circ} \mathrm{C}$ after artificial weathering. Gloss changes were the lowest of thermally modified Scots pine for $4 \mathrm{~h}$ at $200^{\circ} \mathrm{C}$ after artificial weathering. According to our results, the gloss change of unmodified Scots pine was higher than thermally modified Scots pine after artificial weathering. Artificial weathering decreased gloss values of Scots pine specimens to some extent. The gloss values of the unmodified and thermally modified Scots pine wood decreased by $1,04 \%$ to $21,12 \%$ after artificial weathering. There was a statistical difference between glossiness values of unmodified Scots pine wood and thermally modified Scots pine after artificial weathering. The results showed that generally, gloss values of Scots pine wood specimens improved with increasing treatment temperature and duration after artificial weathering.

Table 2. Glossiness values of Scots pine (Pinus sylvestris) before and after artificial weathering.

\begin{tabular}{|c|c|c|c|c|c|}
\hline Temp. & Hours & $\begin{array}{l}\text { Before artificial weathering } \\
\text { glossiness }\end{array}$ & $\begin{array}{l}\text { After artificial weathering } \\
\text { glossiness }\end{array}$ & Differences & Differences (\%) \\
\hline \multicolumn{2}{|c|}{ Unmodified } & $2,84(0,58)$ & $2,24(0,56)$ & $-0,60^{f}$ & $-21,12$ \\
\hline \multirow{3}{*}{140} & 2 & $3,14(0,77)$ & $2,65(0,82)$ & $-0,49^{\mathrm{e}}$ & $-15,60$ \\
\hline & 4 & $2,74(0,35)$ & $2,47(0,67)$ & $-0,27^{\text {cd }}$ & $-9,85$ \\
\hline & 8 & $2,50(1,18)$ & $2,12(0,88)$ & $-0,38^{\mathrm{e}}$ & $-15,20$ \\
\hline \multirow{3}{*}{170} & 2 & $2,86(1,30)$ & $2,60(0,83)$ & $-0,26^{\mathrm{cd}}$ & $-9,09$ \\
\hline & 4 & $2,76(0,98)$ & $2,46(0,54)$ & $-0,30^{\mathrm{d}}$ & $-10,86$ \\
\hline & 8 & $2,52(1,19)$ & $2,35(0,91)$ & $-0,17^{\mathrm{bc}}$ & $-7,23$ \\
\hline \multirow{3}{*}{200} & 2 & $2,64(0,86)$ & $2,36(0,65)$ & $-0,28^{d}$ & $-10,60$ \\
\hline & 4 & $1,92(0,70)$ & $1,90(0,74)$ & $-0,02^{\mathrm{a}}$ & $-1,04$ \\
\hline & 8 & $1,58(0,26)$ & $1,51(0,46)$ & $-0,07^{\mathrm{ab}}$ & $-4,63$ \\
\hline
\end{tabular}

Note: Five replications were made for each group. Small letters given as superscript over glossiness values represent homogeneity groups (HG) obtained by statistical analysis with similar letters reflecting statistical insignificance at the $95 \%$ confidence level. Values in parenthesis are standard deviations.

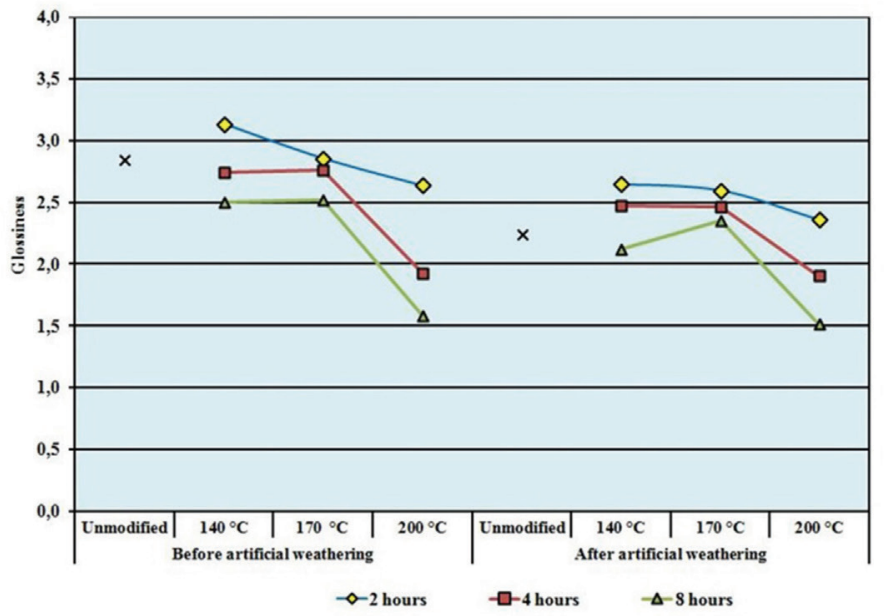

Figure 4. Glossiness of unmodified and thermally modified Scots pine (Pinus sylvestris) after artificial weathering. 


\section{Color changes}

The changes of $\Delta L^{*}, \Delta a^{*}, \Delta b^{*}$, and $\Delta E^{*}$ after artificial weathering of thermally modified Scots pine are given in table 3 . The decrease in $L^{*}$ indicates that the specimens become darker after artificial weathering. $\Delta L^{*}$ of unmodified Scots pine specimen was higher than thermally modified Scots pine specimens after artificial weathering. While $\Delta L^{*}$ of unmodified Scots pine was $(-12,37)$, it changed from $(-0,47)$ to $(-11,65)$ for thermally modified Scots pine after artificial weathering. Generally, darkening with artificial weathering decreased with treatment temperature and duration. For instance, while $\Delta L^{*}$ of Scots pine decreased by 11,$65 ; 11,27$ and 7,57 for $2 \mathrm{~h}, 4 \mathrm{~h}$, and $8 \mathrm{~h}$ of treatment at $140{ }^{\circ} \mathrm{C}$, respectively, it decreased by 3,$18 ; 1,00$ and 0,47 for $2 \mathrm{~h}, 4 \mathrm{~h}$, and $8 \mathrm{~h}$ of treatment at $200^{\circ} \mathrm{C}$. The darkening of Scots pine might be due to degradation of lignin and other non-cellulosic polysaccharides (Hon and Chang 1985, Grelier et al. 2000, Petric et al. 2004). The positive values of $\Delta a^{*}$ indicate a tendency of wood surface to become reddish. In general, the $\Delta a *$ of artificial weathered Scots pine decreased with treatment temperature and duration. For artificially weathered Scots pine, $\Delta a^{*}$ varied between $0,19 \%$ and $6,50 \%$. Our results showed that $\Delta a^{*}$ of unmodified Scots pine specimen gave nearly similar results with thermally modified Scots pine specimen for $2 \mathrm{~h}$ at $140^{\circ} \mathrm{C}, 170^{\circ} \mathrm{C}$, and $200^{\circ} \mathrm{C}$, respectively. Moreover, no statistical differences were found between $\Delta a^{*}$ of unmodified Scots pine and thermally modified Scots pine for $2 \mathrm{~h}$ at $140^{\circ} \mathrm{C}$, $170^{\circ} \mathrm{C}$, and $200^{\circ} \mathrm{C}$, respectively. Positive values of $\Delta b^{*}$ indicate a tendency of wood surface to yellowing. This increase may be explained by the modification of some chromophoric groups of lignin (Grelier et al. 2000). Our results showed that $\Delta b^{*}$ of thermally modified Scots pine wood for $8 \mathrm{~h}$ at $200{ }^{\circ} \mathrm{C}$ was highly lower than other treatments. However except for $8 \mathrm{~h}$ at $170{ }^{\circ} \mathrm{C}$ and for 4 and $8 \mathrm{~h}$ at $200{ }^{\circ} \mathrm{C}$, no statistical differences were found between $\Delta b^{*}$ of unmodified Scots pine and thermally modified Scots pine. Srivinas and Pandey (2012) investigated the color changes of thermally treated rubberwood after accelerated weathering. They found that $\Delta a^{*}$ and $\Delta b^{*}$ increased with exposure duration. The results of this study are consistent with these finding. While, the total color changes $\Delta E^{*}$ of unmodified Scots pine wood was 16,98 it was changed from 1,80 to 17,78 for thermally modified Scots pine (Figure 5). Generally, $\Delta E^{*}$ of Scots pine wood decreased with temperature and duration.

Table 3. Color changes of Scots pine (Pinus sylvestris) before and after artificial weathering.

\begin{tabular}{|c|c|c|c|c|}
\hline \multirow[t]{2}{*}{ Temp. } & \multirow[t]{2}{*}{ Hours } & \multicolumn{3}{|c|}{ Before artificial weathering } \\
\hline & & $\mathrm{L}^{*}$ & $a^{*}$ & $b^{*}$ \\
\hline \multicolumn{2}{|c|}{ Unmodified } & 69,15 & 10,11 & 21 , \\
\hline & 2 & 65,58 & 9,91 & 19 , \\
\hline \multirow[t]{3}{*}{140} & 4 & 67,05 & 10,27 & 21 , \\
\hline & 8 & 63,84 & 10,07 & 19 , \\
\hline & 2 & 66,20 & 9,63 & 19 , \\
\hline \multirow[t]{3}{*}{170} & 4 & 59,16 & 9,74 & 18 , \\
\hline & 8 & 54,24 & 10,13 & 19 , \\
\hline & 2 & 58,60 & 9,81 & 18 , \\
\hline \multirow[t]{2}{*}{200} & 4 & 43,52 & 9,03 & 16 , \\
\hline & 8 & 29,55 & 5,52 & \\
\hline
\end{tabular}

\begin{tabular}{cccc}
\multicolumn{3}{c}{ After artificial weathering } \\
$\Delta \mathrm{L}^{*}$ & $\Delta \mathrm{a}^{*}$ & $\Delta \mathrm{b}^{*}$ & $\Delta \mathrm{E}^{*}$ \\
$-12,37^{\mathrm{f}}$ & $5,71^{\mathrm{cd}}$ & $10,14^{\mathrm{c}}$ & $16,98^{\mathrm{e}}$ \\
$-11,65^{\mathrm{ef}}$ & $6,50^{\mathrm{d}}$ & $11,76^{\mathrm{c}}$ & $17,78^{\mathrm{e}}$ \\
$-11,27^{\mathrm{ef}}$ & $5,11^{\mathrm{cd}}$ & $9,99^{\mathrm{c}}$ & $15,9 \mathrm{~d}^{\mathrm{e}}$ \\
$-7,57^{\mathrm{d}}$ & $4,45^{\mathrm{bc}}$ & $10,1^{\mathrm{c}}$ & $13,38^{\mathrm{cd}}$ \\
$-9,41^{\mathrm{de}}$ & $6,32^{\mathrm{d}}$ & $12,45^{\mathrm{c}}$ & $16,83^{\mathrm{e}}$ \\
$-4,57^{\mathrm{c}}$ & $5,09^{\mathrm{cd}}$ & $10,63^{\mathrm{c}}$ & $12,64^{\mathrm{cd}}$ \\
$-0,62^{\mathrm{a}}$ & $3,34^{\mathrm{b}}$ & $6,81^{\mathrm{b}}$ & $7,61^{\mathrm{b}}$ \\
$-3,18^{\mathrm{bc}}$ & $5,4^{\mathrm{cd}}$ & $9,66^{\mathrm{c}}$ & $11,51^{\mathrm{c}}$ \\
$-1,00^{\mathrm{ab}}$ & $1,48^{\mathrm{a}}$ & $5,09^{\mathrm{b}}$ & $5,39^{\mathrm{b}}$ \\
$-0,47^{\mathrm{a}}$ & $0,19^{\mathrm{a}}$ & $1,73^{\mathrm{a}}$ & $1,80^{\mathrm{a}}$
\end{tabular}

Note: Five replications were made for each group. Small letters given as superscript over values $\Delta L^{*}, \Delta a^{*}, \Delta b^{*}$ and $\Delta E^{*}$ represent homogeneity groups (HG) obtained by statistical analysis with similar letters reflecting statistical insignificance at the $95 \%$ confidence level. Values in parenthesis are standard deviations. 


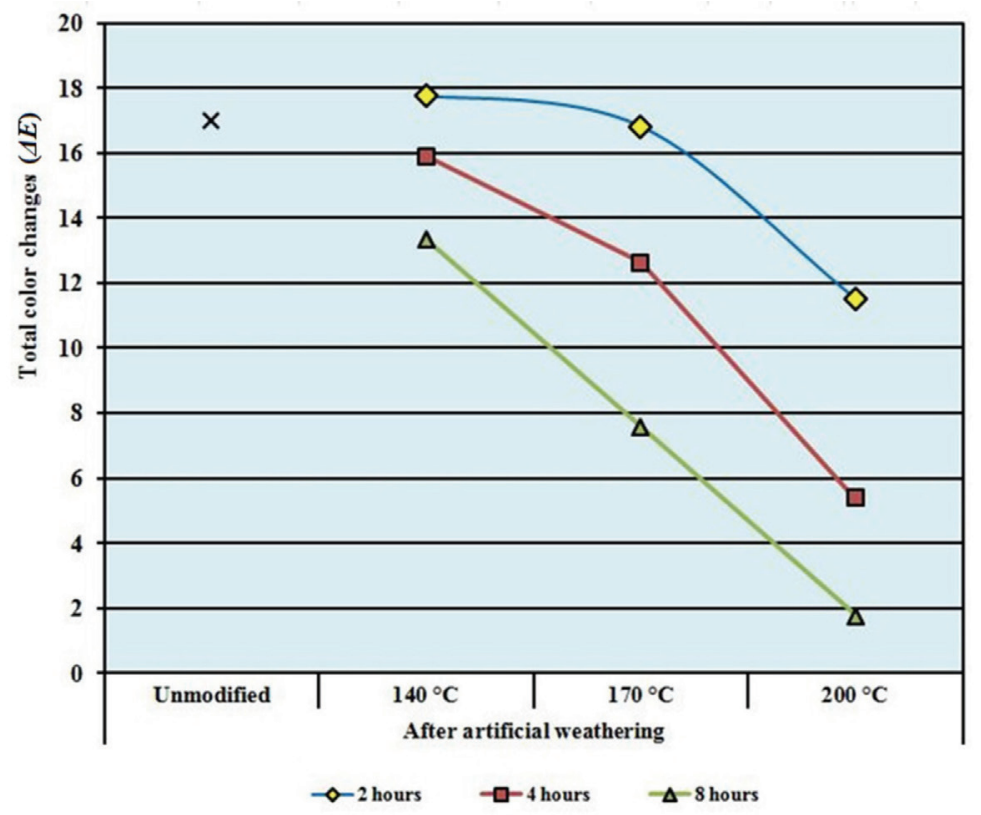

Figure 5. $\Delta E^{*}$ values of unmodified and thermally modified Scots pine (Pinus sylvestris) after artificial weathering.

\section{CONCLUSION}

This study dealt with the surface roughness, glossiness, and color of thermally modified Scots pine wood specimens after artificial weathering. Thermally modified Scots pine showed better surface characteristics than unmodified Scots pine after artificial weathering. While the decrease in $\Delta L^{*}$ indicates that the specimens become darker, positive values of $\Delta a^{*}$ and $\Delta b^{*}$ indicate a tendency of wood surface to become reddish and yellowish, respectively. In general, higher temperature and duration of Scots pine resulted in lower surface roughness and higher glossiness of Scots pine wood after artificial weathering.

As a result, thermally treated wood gets a look of old wood and is used for imitation of the rustic building, and the superheated leaved give the impression of exotic wood (Vukas et al. 2010). Moreover, heat-treated wood possesses new physical properties such as reduced hygroscopy, improved dimensional stability and weathering properties, better resistance to degradation by insects and micro-organisms, and most importantly, attractive darker color. The new versatile properties make heat-treated wood popular for outdoor applications (Huang et al. 2013).

\section{REFERENCES}

Akgul, M.; Korkut, S. 2012. The effect of heat treatment on some chemical properties and colour in Scots pine and Uludağ fir wood. African Journal of Biotechnology 7(21): 2854-2859.

ASTM D 1536-58. 1964. Tentative method of test color difference using the colormaster differential colourimeter.

ASTM D 523-08. 2008. Standard method of test for specular gloss. West Conshohocken.

ASTM G 154. 2006. Standard practice for operating fluorescent light apparatus for UV exposure of nonmetallic materials. West Conshohocken.

Ayadi, N.; Lejeune, F.; Charrier, F.; Charrier, B.; Merlin, A. 2003. Colour stability of heat treated wood during artificial weathering. Holz Roh Werkst 61: 221-226. 
Baysal, E. 2012. Surface characteristics of CCA treated scots pine after accelerated weathering. Wood Research 57(3): 375-382.

Beckers, E.P.J.; Stevens, M.; Meijer, M. de; Militz, H. 1998. Performance of finishes on wood that is chemically modified by acetylation. Journal of Coatings Technology 70(878): 59-67.

Cakicier, N.; Korkut, S.; Korkut, D.S. 2011. Varnish layer hardness, scratch resistance, and glossiness of various wood species as effected by heat treatment. Bioresources 6(2): 1648-1658.

DIN 4768. 1990. Determination of values of surface roughness parameters Ra, Rz, Rmax using electrical contact (stylus) instruments. Concepts and measuring conditions, Deutsches Institut für Norming, Berlin, Germany.

Denes, AR.; Young, R.A. 1999. Reduction of weathering degradation of wood through plasma-polymer coating. Holzforschung 53(6): 632-640.

Dundar, T.; Nusret, As.; Korkut.; S, Unsal, Ö. 2008. The Effect of Boiling Time on The Surface Roughness of Rotary-Cut Veneers from Oriental beech (Fagus orientalis L.). J Mater Process Tech 199(1-3): 119-123.

Esteves, B.; Marques, A.V.; Domingos, I.; Pereira, H. 2008. Heat-induced colour change of pine (Pinus pinaster) and eucalypt (Eucalyptus globulus) wood. Wood Sci Technol 42(5): 369-384.

Evans, P.D.; Michell, A.J.; Schmalzl, K.J. 1992. Studies of the degradation and protection of wood surfaces. Wood Sci Technol 26(2): 151-163.

Evans, P.D.; Owen, N.L.; Schmid, S.; Webster, R.D. 2002. Weathering and photostability of benzoylated wood. Polym Degrad Stabil 76(2): 291-303.

Feist, W.C. 1979. Protection of wood surfaces with chromium trioxide. Res. Pap. FPL 339. Madison, WI: U.S. Department of Agriculture, Forest Service, Forest Products Laboratory.

Feist, W.C.; Hon, D.N.S. 1984. Chemistry of weathering and protection- In: "The chemistry of solid wood," R.M. Rowell, ed. Advances in chemistry series 207,” Am. Chem. Soc., Washington D.C.

Grelier, S.; Castellan, A.; Desrousseaux, S.; Nourmamode, A.; Podgorski, L. 1997. Attemp to protect wood colour against UV/visible light by using antioxidants bearing isocyanate groups and grafted to the material with microwave. Holzforschung 51(6): 511-518.

Grelier, S.; Castellan, A.; Kamdem, D.P. 2000. Photo-protection of copper amine treated wood. Wood Fiber Sci 32(2): 196-202.

Gunduz, G.; Aydemir, D. 2009. Some physical properties of heat-treated Hornbeam ( Carpinus betulus) wood. Drying Technol 27(5): 714-720.

Hill, C.A.S. 2006. Wood modification: chemical, thermal and other processes. Chichester: John Wiley and Sons.

Hiziroglu, S. 1996. Surface roughness analysis of wood composites: a stylus method. Forest Prod $J$ 46: 67-72.

Hiziroglu, S.; Graham, S. 1998. Effect of press closing time and target thickness on surface roughness of particleboard. Forest Prod J 48: 50-54.

Hon, D.N.S.; Chang, S.T. 1985. Photoprotection of wood surfaces by wood-ion complexes. Wood Fiber Sci 17(1): 92-100.

Huang, X.; Kocaefe, D.; Kocaefe, Y.; Boluk, Y.; Krause, C.; 2013. Structural analysis of heat-treated birch (Betule papyrifera) surface during artificial weathering. Appl Surf Sci 264: 117-127. 
Jebrane, M.; Sébe, G. 2007. A novel simple route to wood acetylation by transesterification with vinyl acetate. Holzforschung 61(2): 143-7.

Jebrane, M.; Sébe, G. 2008. A new process for the esterification of wood by reaction with vinyl esters. Carbohyd Polym 72(4): 657-63.

Karagoz, U.; Akyildiz, M.H.; Isleyen, O. 2011. Effect of heat treatment on surface roughness of thermal wood machined by CNC. Pro Ligno 7(4): 50-58.

Kiguchi, M.; Evans P.D. 1998. Photostabilisation of wood surfaces using agrafted benzophenone UV absorber. Polym Degrad Stabil 61(1): 33-45.

Korkut, S.D.; Hiziroglu, S.; Aytin A. 2013. Effect of heat treatment on surface chracteristics of wild cherry wood. Bioresources 8(2): 1582-1590.

Meijer, M. 2001. Review on the durability of exterior wood coatings with reduced VOC-content. Prog Org Coat 43: 217-225.

Nuopponen, M.; Wikberg, H.; Vuorinen, T.; Sirkka, L.M.; Jämsä, S.; Viitaniemi, P.; 2004. Heat-treated softwood exposed to weathering. J Appl Poly Sci 91: 2128-2134.

Pandey, K.K.; Chandrashekar, N. 2006. Chandrashekar N. Photostability of wood surfaces esterified by benzoyl chloride. J Appl Polym Sci 99(5): 2367-74.

Petric, M.; Kricej, B.; Humar, H.; Pavlic, M.; Tomazic, M. 2004. Patination of cherry wood and spruce wood with ethanolamine and surface finishes. Surface Coatings International Part B: Coatings Transactions 87(B3): 95-201.

Rowell, R.M. 1983. Chemical modification of wood. For Prod Abstracts 6(12): 363-82.

Sehlstedt-Persson, M. 2003. Colour responses to heat treatment of extractives and sap from pine and spruce. In: 8th International IUFRO Wood Drying Conference. Brasov Romania. pp 459-464.

Srinivas, K.; Pandey, K.K. 2012. Photodegradation of thermally modified wood. J Photoch Photobio B 117: $140-145$.

Sundqvist, B. 2004. Colour changes and acid formation in wood during heating. Doctoral Thesis, Lulea University of Technology, Sweden.

Temiz, A.; Terziev, N.; Jacobsen, B.; Eikenes, M. 2006. Weathering, water absorption, and durability of silicon, acetylated, and heat-treated wood. J Appl Poly Sci 102: 4506-4513.

Vukas, N.; Horman, I.; Hajdarević, S. 2010. Heat treated wood. 14 $4^{\text {th }}$ International Research/Expert Conference "Trends in the Development of Machinery and Associated Technology"TMT 2010, Mediterranean Cruise, 11-18 September 20, 121-124 pp.

Williams, R.S. 1983. Effect of grafted UV stabilizers on wood surface erosion and clear coating performance. J Appl Polym Sci 28(6): 2093-2103.

Yalinkilic, M.K.; Ilhan, R.; Imamura, Y.; Takahashi, M.; Demirci, Z.; Yalinkilic, A.C.; Peker, H. 1999. Weathering durability of CCB-impregnated wood for clear varnish coatings. J Wood Sci 45(6): 502-514.

Yildiz, S.; Tomak, E.D.; Yildiz, C.; Ustaomer, D. 2013. Effect of artificial weathering on the properties of heat treated wood. Polym Degrad Stabil 98(8): 1419-1427.

Zhang, X. 2003. Photo-resistance of alkylammonium compound treated wood. MSc. Thesis. The University of British Colombia Vancouver, Canada. 